\title{
Environmental impacts of intensive deer farming in New Zealand - a review
}

\author{
C.A.M. de KLEIN ${ }^{1}$, J. J. DREWRY' ${ }^{1}$, J. W. NAGELS ${ }^{2}$, M. SCARSBROOK², R. COLLINS ${ }^{2}$, R.W. \\ $\mathrm{M}^{\mathrm{C}}$ DOWELL $^{1}, \mathrm{R}$. MUIRHEAD ${ }^{1}$ \\ ${ }^{I}$ AgResearch, Invermay Agricultural Research Centre, Private Bag 50034, Mosgiel \\ ${ }^{2}$ NIWA, Hamilton, PO Box 11-115, Hamilton \\ cecile.deklein@agresearch.co.nz
}

\begin{abstract}
The New Zealand deer industry is growing rapidly and the development of sustainable management practices for deer farming is becoming increasingly important. The main environmental issues facing the deer industry are the eff ects on soil and water quality, exacerbated by the behaviour responses of deer to confinement (in particular fence pacing and wallowing). In addition, the projected increase in greenhouse gas emissions from deer farming from about $1.5 \%$ of the total emissions in 1990 to an estimated $7 \%$ in 2010 is of particular concern if the Kyoto Protocol is ratified. Although the potential effects of deer farming on the environment are well recognised, very little experimental work has qualified the extent of these impacts. The future of intensive deer farming in New Zealand will not only depend on the successful development of sustainable management practices, but also on the implementation and adoption of these practices, which will be influenced by the balance between the costs and the benefits to the New Zealand deer farmer. The development and adoption of sustainable management practices for deer farming requires quantification of rates of sediment, nutrient and faecal contaminant movement to waterways, the impact of soil compaction and greenhouse gas emissions, as well as an assessment of the economic implications.
\end{abstract}

Keywords: deer farming, greenhouse gas emissions, nutrient losses, sediment losses, soil compaction, soil erosion, water quality

\section{Introduction}

The New Zealand deer industry is relatively young but expanding rapidly, with deer numbers increasing from about 1 million in 1990 to 2.6 million in 2001 (Baisden et al. 2001; New Zealand Game Industry Board 2001). New Zealand is the world's largest supplier of venison, velvet and other deer products. The major overseas markets are Europe, receiving approximately $80 \%$ of all venison exports, and Korea, with approx. $90 \%$ of all velvet exports (New Zealand Game Industry Board 2001). Overseas consumers, particularly those in Europe, are increasingly concerned not only about the health and welfare of the animals but also the health and sustainability of the environment where the animals are raised. The long-term profitability of deer farming is therefore inextricably linked to the health of the farming envir onment (New Zealand Deer Farmers'Association 2001), and the development and adoption of sustainable management practices for intensive deer farming will be critical for maintaining New Zealand's 'clean green' image overseas (Rowarth et al. 2000). Other drivers for developing sustainable management practices for deer farming are the protection of our natural resources, New Zealand's commitment to international agreements, and tourism. The New Zealand deer industry has been proactive in developing improved management practices, for example by initiating the Deer Farmers' Environment Awards, developing a Deer Farmers' Landcare Manual (New Zealand Deer Farmers' Association 2001), and direct involvement in the development of standards for livestock production (Standards New Zealand). This paper reviews the existing scientific knowledge on the environmental impacts of intensive deer farming to identify research that is required to achieve sustainable deer production systems.

\section{Environmental impacts of deer production systems - current understanding}

\section{Soil and water quality}

The main environmental issues facing the deer industry are the effects of intensive deer farming on soils through compaction and erosion, and effects on water quality and aquatic habitats through eutrophication, sediment loss, and faecal contamination. These problems arise partly from the behavioural response of deer to confinement (e.g. fence pacing), and also from the propensity of deer to seek water for playing and wallowing. Fence pacing is prevalent at mating, weaning and calving and at other times when the deer are under stress (Moore et al. 1985). Fence pacing causes soil compaction and increased erosion through the loss of vegetation and soil structure, while wallowing can destroy wetland areas and may enhance erosion of the riparian margins and banks of small streams. Soil compaction, soil erosion and runoff can create subsequent problems of eutrophication, sediment loss and faecal contamination of waterways.

Eutrophication is the enrichment of surface waters with nutrients, which can accelerate the growth of nuisance algae and weeds, while organic enrichment can increase the microbial activity in waterways. Nuisance plants and microbial respiration can deplete dissolved oxygen, 
which in turn can lead to fish stress and even death. In some cases the levels of some contaminants (e.g. ammonia) may cause poisoning of aquatic life. Contamination of waterways with nitrate- $\mathrm{N}$ is also considered an important environmental concern and various nutrient leaching studies have been carried out recently, particularly on dairy farms (Ledgard et al. 1999a; Monaghan et al. 2000). However, it is currently believed that nitrate leaching from deer farms is less than from dairy or cattle farms due to more efficient cycling of nitrogen in deer excreta. Nitrate leaching for deer farms is likely to be similar to that from sheep farms.

The loss of soils to waterways as a result of erosion not only loses valuable farm resources, but also contributes to degraded water quality and aquatic habitats. Suspended sediments reduce water clarity and light penetration (Davies-Colley et al. 1992) and can elicit avoidance responses in native fish species (Boubée $e t$ al. 1997). Fine sediment deposits on the streambed further degrade habitat quality and reduce the carrying capacity for invertebrates (Suren \& Jowett 2001), native fish (Jowett \& Boustead 2001; Rowe et al. 2000) and introduced salmonids (Waters 1995). Soil erosion can also accelerate phosphate (P) losses from most agricultural systems (McDowell et al.2001b), as much phosphate transfer is associated with sediment movement.

The microbiological contamination of waterways with faecal bacteria creates health risks for human and stock (Environment Southland 2000), as many diseases identified in NZ deer herds (Gill 1998) are considered important water borne diseases in NZ (Ball \& Till 1998). These include diseases that are common to all types of pastoral mammals e.g. Lepospirosis, Johne's disease, internal parasites, Cryptosporidiosis, and Yersiniosis.

Little experimental evidence exists of the direct impacts of deer farming on soil and water quality although several anecdotal records and visual observations by industry staff have been reported (e.g. The Deer Farmer i.e., 2001 Annual editorial on $\mathrm{p}$ 34). The existing scientific knowledge relevant to deer farming and soil and water quality is summarised in the following two sections.

\section{Soil compaction and erosion}

A recent pilot study is the only known investigation of the effect of fence pacing during deer calving on soil compaction (Pollard \& Drewry 2002). The results showed that deer paddock tracks were very compact, particularly on sloping land. Although the compacted areas were confined to the tracks and the effects on pasture production likely to be limited, increased soil compaction is expected to increase overland flow of nutrients. Research on the impact of sheep and cattle treading in hill country (Nguyen et al. 1998; Sheath \& Carlson 1998) showed that treading damage reduced water infiltration, which in turn led to increased sediment loss and nutrient losses following rainfall. These studies also showed that the concentration of suspended solids and nutrients tended to increase with an increase in soil damage, particularly in steeper areas. Recent studies by Elliott et al. (2002) using rainfall simulators and grazing animals showed significant losses of sediments, nutrients and faecal coliforms with grazing sheep on a hill country farm. Elliot \& Carlson (2002) used modelling techniques to develop measures to mitigate treading related erosion.

Thorrold \& Trolove (1996) measured the effect of deer faming on soil erosion in a small survey in the Ngongotaha Valley, Lake Rotorua. They estimated that the amount of sediment generated in three deer paddocks was $2.1,2.2$ and $22 \mathrm{t} / \mathrm{ha} /$ year, i.e. erosion in one paddock was about 10 times higher than in the other two paddocks. Sediment and nutrient loss under deer farming can be simulated using field-scale agricultural models. Simulations conducted by Rodda et al. (2001), for example, suggested that sediment loss from land under deer farming was up to four and a half times greater than from land under other livestock farming or forestry. The simulations also predicted that sediment yield could be halved if deer farming was restricted to slopes under $20 \%$, and that further benefits would arise if riparian buffer zones were used. Recent measurements by Environment Southland on the effect of deer wallowing on water quality showed that the concentrations of ammoniacal-N and suspended solids in a waterway downstream of a deer wallowing site were about 25 and 35 times higher, respectively, than upstream of the wallowing site (Environment Southland 2000). The report suggested that the downstream concentrations of ammoniacal-N were toxic to fish life, while the concentration of suspended solids represented soil erosion losses of over 2.3 tonnes per day. Although the study did not include measurements of phosphate concentration in the stream, based on the estimated soil erosion loss of 2.3 tonnes per day and $\mathrm{P}$ concentrations in soil of around 0.1 to $0.3 \%, \mathrm{P}$ losses to the stream could be about 2 to $7 \mathrm{~kg}$ P per day. Using an indexing approach McDowell et al. (2001a) have shown that the majority of P loss events occur from "hot-spots" within a catchment, which comprise only a small part of that catchment. This approach predicts $\mathrm{P}$ loss by combining simple farming or management factors (e.g., fence pacing or fertiliser use) with soil and climatic factors likely to encourage P movement. Such an approach can therefore highlight areas within a catchment that are at greatest risk of $\mathrm{P}$ losses and where management practices to reduce erosion losses will have the biggest impact.

The increased level of suspended solids reported by Environment Southland is equivalent to levels associated with gold mining on the West Coast of the South Island 
(Davies-Colley et al. 1992). These levels caused major impacts on stream productivity and invertebrate communities (Quinnet al. 1992). The suspended solids concentration of about $275 \mathrm{~g} / \mathrm{m}^{3}$ recorded by Environment Southland below the deer wallowing site could cause turbidities of as high as 300 NTU, exceeding, by an order of magnitude, the recommended guidelines for the management of freshwater fisheries of 25 NTU.

\section{Faecal contamination}

Faecal contamination of waterways is caused through direct inputs of faeces into farm waterways, or via the disposal of waste from the deer slaughter plants. Williams $\&$ Haynes (1995) showed that concentrations of P and $\mathrm{N}$ of deer manure were less than in dairy manure, and suggested that the risk of water contamination from deer farms is likely to be less than for cattle farms. However, dung patches could become a major source of contamination if deer deposit their faeces in areas that are exposed to significant erosion (e.g. tracks) and/or in wallows. The recent measurements by Environment Southland (2000) on the effect of deer wallowing on water quality also showed that downstream concentrations of faecal coliforms were about 20 times higher than upstream of the wallowing site.

In a recent study of eight dairying catchments around New Zealand, the effects of deer on faecal contaminant levels in waterways were serendipitously assessed (Davies-Colley \& Nagels 2002). In one of the catchments (Piakonui, Waikato) two large deer farms (550 and 250 animals per farm) were observed immediately upstream of a regular monthly sampling station. A second sampling site was added to provide an assessment of background levels of coliform bacterial above these deer farms. Over the 13 sampling occasions, Escherichia coli (E. coli) levels below the deer farms were 2-10 times higher than above the farms (Fig. 1), despite the presence of two dairy farms above the baseline sampling site. Significant areas of deer wallow were observed in small streams and wetlands feeding into the Piakonui Stream, and these are expected to be the potential sources of contamination. Direct cattle access to streams and subsequent direct deposition of faecal matter into waterways has been recently studied by Davies-Colley et al. (2002). In this study, they found that cows were 50 times more likely to defecate in stream water than on adjacent raceways when crossing the stream on the way to and from milking. The authors concluded that preventing cattle access to streams by providing bridges should yield major water quality benefits.

More recently, Campylobacter species have been studied in freshwater environments and found to be present in a variety of waters draining from pastoral agriculture, including predominantly deer farmed
Figure 1 E. coli recorded upstream and immediately downstream of two deer farms in the Piakonui catchment (Waikato).

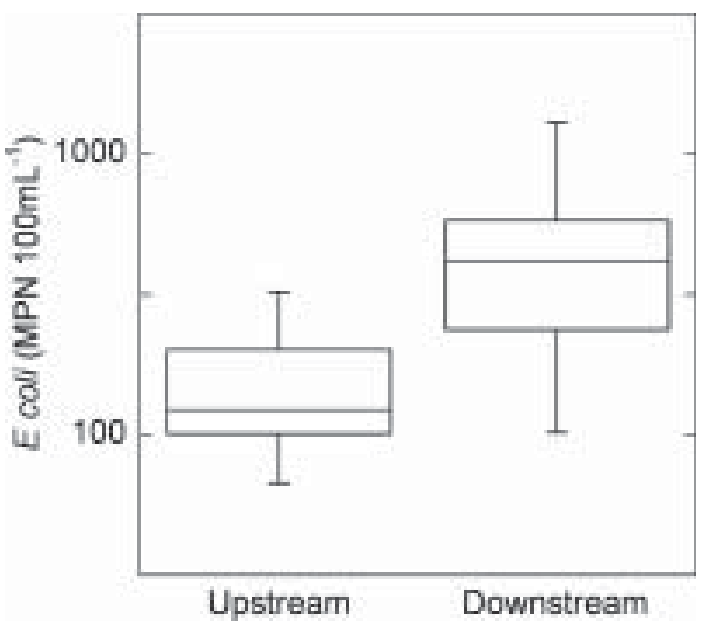

catchments. Eyles et al. (2002) found streams draining deer farms showed high average levels of thermo-tolerant Campylobacter (TTC), second only to dairy catchments, whereas very low levels were detected in streams of ungrazed tussock and sheep farms in the Taieri catchment. During flood events, peak TTC levels were two orders of magnitude greater than pre- flood conditions. They conclude that the current shift to more intensive land use (i.e. dairy and deer farming) may lead to further increases in contamination of freshwaters. These findings are consistent with a growing body of work recently summarised by Parkyn et al. (2002) showing a general degradation of water quality and stream 'health' by pastoral agriculture.

Recently, a model has been developed to predict concentrations of $E$. coli in streams draining hill-country pastures grazed by sheep and beef cattle (Collins \& Rutherford 2002). The long-term aim of this modelling is to aid assessment of the impact of land management practices upon faecal contamination. Given appropriate data, for example the amount of material excreted directly into streams (at wallowing sites) and some experimental record to calibrate certain key processes, the model could be adapted to deer farming. A daily record of grazing livestock is used in the current model to estimate $E$. coli inputs to a catchment, and such an approach would be applicable to deer assuming the amount and indicator/ pathogen content of their faecal material is known. The model enables scenarios such as excluding stock from stream channels, and riparian retirement to be assessed.

It is often difficult to unequivocally determine the sources of faecal contaminants, and hence properly apportion blame and direct mitigation efforts. However, new techniques that have been developed recently have great potential for determining the relative contributions 
of faecal material from different animal sources. These include using antibiotic resistance in faecal streptococcus isolates (Hagedorn et al. 1999), and extracting the DNA from Rhodococcus coprophilus (a natural inhabitant of herbivore faeces) and using PCR methods to determine the host mammalian species (including deer) from which the bacteria was derived (Savill et al. 2001).

\section{Air quality - greenhouse gas emissions}

The estimated contribution of the deer industry to New Zealand's agricultural greenhouse gas emissions is rela tivel y small compared to the sheep and dairy industry, and financial results published in the MAF farm monitor ing reports (Ministry of Agriculture and Forestry 2001c) suggest that, in 1999, the deer industry generated about twice as much profit per unit of greenhouse gas emitted than the sheep/beef industry. However, the contribution of the deer industry to total emissions has doubled from about $1.5 \%$ in 1990 to about 3\% in 1999 (Table 1), and is expected to rise to $7 \%$ by 2010 . These

Table 1 Relative contribution (\%) of animal sectors to total greenhouse gas emissions from livestock in New Zealand in 1990 and 1999 (adapted from Baisden et al. 2001; Ministry of Agriculture and Forestry 2001a).

\begin{tabular}{lccc}
\hline Livestock type & 1990 & 1999 & 2010 \\
\hline Sheep & 58 & 48 & 35 \\
Dairy Cattle & 19 & 25 & 32 \\
Beef Cattle & 21 & 23 & 24 \\
Deer & 1.5 & 3 & 7 \\
\hline
\end{tabular}

recent increases in greenhouse gas emission from deer farming could become of particular importance when the Kyoto Protocol comes into effect. Ratification of the Kyoto Protocol will commit New Zealand to reduce its greenhouse gas emissions to 1990 levels between 2008 and 2012 (New Zealand Climate Change Programme 2001). Agriculture contributes about $55 \%$ to New Zealand's total greenhouse gas emissions (de Klein et al. 2002). These agricultural emissions are largely due to methane $\left(\mathrm{CH}_{4}\right)$ and nitrous oxide $\left(\mathrm{N}_{2} \mathrm{O}\right)$ emissions, while the remaining $45 \%$ are mainly due to carbon dioxide $\left(\mathrm{CO}_{2}\right)$ emissions from industry and transport. In New Zealand, the principal source of methane is enteric fermentation in the digestive tract of ruminants. Nitrous oxide emissions from agriculture are largely a result of the deposition of excreta nitrogen to the soil when the animals are grazing, particularly when soils are wet and/ or compacted (de Klein et al.2001).

\section{Minimising the envir onmental impact of deer production systems}

While there is an extensive literature on the mitigation of environmental effects associated with pastoral agriculture (e.g. Ledgard et al. 1999a; Monaghan et al. 2000; Parkyn et al. 2002), a review of the national and international literature did not reveal any scientific studies on mitigation options for reducing soil compaction, erosion, and contamination of waterways specific to deer farming. Given the major role New Zealand plays in the deer industry worldwide, New Zealand may need to take a lead internationally in defining environmental impacts and developing mitigation measures. As a starting point, many mitigation practices are derived from studies of other pastoral agriculture systems (e.g. cattle and sheep) and anecdotal observations. Some options are summarised below.

The deer farming community has adopted various techniques to reduce the risk of erosion: altering placement of fence lines, use of electric fencing, visual barriers between mobs, and shifting deer regularly (Anon 2000). In a recent survey of deer farmers, $80 \%$ of the respondents believed that pacing along fence lines could be reduced by the presence of trees and shrubs to provide shade and shelter (Pollard 2001).

Other management practices that are promoted include avoiding frequent grazing of pasture during drought or wet or cold weather, avoiding heavy grazing, filling in eroded fence lines with gravel or placement of gravel piles to slow water movement, careful siting of fences, fencing off and placement of riparian areas with suitable buffer zones near waterways, alternative reticulated water supply, and bridge or culveted water body crossings (Malcolm 1996; Ministry for the Environment 2001; Otago Regional Council 1996; Thorrold \& Trolove 1996). Although not specifically deer-related, the Ministry for the Environment (2001) also presented the general principles of reducing soil erosion. These include reducing pasture damage particularly on wet areas prone to treading and pugging damage; avoiding overgrazing; minimising, intercepting or slowing surface runoff; and constructing adequate farm road drainage. A deer farmer in South Canterbury created a planked walkway and platform to provide deer with access to Ohape Creek for watering, while protecting the banks and avoiding deposition of excreta into waterways (Adrian Meredith, Environment Canterbury pers. comm.). Nguyen et al. (2002a; 2002b) showed that well vegetated drainage ditches could reduce the impact of pollutants from dairy farms. Their results showed that close to $100 \%$ of $E$. coli bacteria that were introduced at the headwaters were removed in a $150 \mathrm{~m}$ vegetated ditch (Nguyen et al. 2002a), while $44 \%$ of ammonium and $56 \%$ of dissolved reactive phosphate introduced at the head waters was retained in the $150 \mathrm{~m}$ vegetated ditch during the $22 \mathrm{~h}$ study period (Nguyen et al. 2002b). However, Nguyen et al. (2002a) also concluded that since $E$. coli has been found to survive in freshwater sediment, any sediment disturbance (e.g. 
high water flows, animal trampling, vegetation removal) is likely to re-mobilise the trapped E. coli. Modelling faecal transport is also a powerful way to gain insight into improving management techniques to prevent disease organisms spreading in the aquatic environment.

To determine the potential nutrient losses to the environment, a nutrient budget could be calculated using the nutrient budgeting model OVERSEER ${ }^{\circledR}$ (Ledgard $e t$ al. 1999b). An example of the outputs of this model is given in Table 2, for a MAF model deer farm (Ministry of Agriculture and Forestry 2001b). OVERSEER ${ }^{\circledR}$

Table 2 A nutrient budget for a North Island model deer farm (Ministry of Agriculture and Forestry 2001b) calculated using the nutrient budgeting model OVERSEER ${ }^{\circledR}$. Farm N surplus and leaching losses are also given.

\begin{tabular}{|c|c|c|c|c|}
\hline \multicolumn{5}{|l|}{ Farm details } \\
\hline $\begin{array}{l}\text { Effective area } \\
\text { Topography } \\
\text { Clover levels } \\
\text { Rainfall } \\
\text { Soil type } \\
\text { Stocking rate } \\
\text { Farm production }\end{array}$ & $\begin{array}{l}140 \mathrm{ha} \\
\text { Rolling } \\
\text { Medium } \\
1200 \mathrm{~mm} \\
\text { Volcanic } \\
12.7 \mathrm{SU} / \mathrm{ha} \\
916 \mathrm{~kg} \text { velvet }\end{array}$ & & & \\
\hline Nutrient Budget (kg/ha/year) & $\mathrm{N}$ & $P$ & $\mathrm{~K}$ & $\mathrm{~S}$ \\
\hline $\begin{array}{l}\text { Inputs } \\
\text { Fertiliser } \\
\text { Atmospheric ( } \mathrm{N} \text { fixation and rain) } \\
\text { Slow release from soil }\end{array}$ & $\begin{array}{c}20 \\
56 \\
0\end{array}$ & $\begin{array}{r}25 \\
0 \\
3\end{array}$ & $\begin{array}{l}25 \\
2 \\
27\end{array}$ & $\begin{array}{r}31 \\
4 \\
0\end{array}$ \\
\hline $\begin{array}{l}\text { O utputs } \\
\text { Product } \\
\text { Gaseous losses } \\
\text { Leaching/runoff } \\
\text { Immobilisation/absorption }\end{array}$ & $\begin{array}{l}6 \\
34 \\
24 \\
12\end{array}$ & $\begin{array}{c}1 \\
0 \\
1 \\
25\end{array}$ & $\begin{array}{c}1 \\
0 \\
17 \\
0\end{array}$ & $\begin{array}{c}1 \\
0 \\
37 \\
1\end{array}$ \\
\hline \multicolumn{5}{|l|}{ Balance } \\
\hline Nitrogen and the Environment & This farm & & $\mathrm{NZO}$ & \\
\hline $\begin{array}{l}\text { Farm } \mathrm{N} \text { surplus }{ }^{\mathrm{a}}(\mathrm{kg} \mathrm{N} / \mathrm{ha} / \mathrm{year}) \\
\text { Leaching loss ( } \mathrm{kg} \mathrm{N} / \mathrm{ha} / \mathrm{year}) \\
\text { Average nitrate concentration in } \\
\text { drainage water }{ }^{\mathrm{b}}(\mathrm{mg} \mathrm{N} / \mathrm{L})\end{array}$ & $\begin{array}{c}70 \\
24 \\
5 \\
+/- \text { about } 25 \%\end{array}$ & & $\begin{array}{l}30-80 \\
5-25 \\
2-8\end{array}$ & \\
\hline
\end{tabular}

a $\mathrm{Sum}$ of fertiliser and atmospheric $\mathrm{N}$ inputs minus $\mathrm{N}$ output in product.

${ }^{b}$ Recommended maximum for drinking water is $11 \mathrm{mg} \mathrm{N} / \mathrm{L}$.

provides a nutrient budget and an 'Environmental $\mathrm{N}$ page' with results on the $\mathrm{N}$ surplus, nitrate leaching losses and average nitrate concentration in drainage water. The latter results are also compared with values that can be expected for an average New Zealand deer far $m$. Table 2 suggests that the $\mathrm{N}$ surplus and nitrate leaching losses of the MAF model deer farm used in the current example are at the top end of the estimated range for an average New Zealand deer farm. It should be noted, however, that the current model is based on nutrient cycling research on sheep, beef and dairy farms, and more work is required to refine the calculations for deer farming.

Research on mitigation options for reducing methane and/or nitrous oxide emissions from agriculture is limited (Clark 2001). However, de Klein \& Clark (2002) evaluated potential mitigation options for reducing $\mathrm{CH}_{4}$ and $\mathrm{N}_{2} \mathrm{O}$ emissions from dairy cows, which included: i) Diet manipulation; ii) The use of forages or additives to manipulate the microbes in the rumen; iii) Avoiding wet and compacted soil conditions. These mitigation options are likely to be applicable to the deer industry as well.

Diet manipulation (i.e. improved feed quality) can reduce $\mathrm{CH}_{4}$ production per unit of feed intake by increasing animal productivity, as it reduces the proportion of feed required for maintenance. Studies have shown that forage legumes that contain condensed tannins, such as birdsfoot trefoil (Lotus corniculatus), lotus ( $L$. pendunculatus) and sulla (Hedysarum coronarium), can significantly improve animal performance compared to common forage grasses (Hoskin et al. 2000; Waghom \& Sheldon 1997; Woodward et al. 2001). However, the $\mathrm{N}$ excretion rates of deer fed on these high-N legume diets are likely to be higher than for deer on grass diets (Freudenberger et al. 1994; Masuko et al. 1997), which could increase nitrous oxide emissions. Although methane is the main contributor of greenhouse gas emissions from agriculture and the effect of tannin-rich diets on methane emissions has been the focus of recent research (Woodward et al. 2001), a high-energy low-protein diet e.g. maize silage (van Vuuren \& Meijs 1987) that would increase animal productivity and reduce $\mathrm{N}$ excretion rates is likely to reduce both methane and nitrous oxide emissions. Furthermore, feeding deer a low-nitrogen diet has the added advantage of reducing nitrate leaching losses to waterways.

The microbial activity in the rumen can also be affected by certain forages and/or feed additives, although the experimental evidence for the latter is limited. Woodward et al. (2001) found that methane emissions from sheep and dairy cows fed Lotus corniculatus silage were lower per unit of feed intake, compared to animals on ryegrass silage. 
Various studies have shown that $\mathrm{N}_{2} \mathrm{O}$ emissions are enhanced in wet or compacted soil (de Klein et al. 2002; McTaggart et al. 1997; R.A. Carran \& P. Theobald unpublished data). Management practices that reduce or minimise soil compaction should therefore reduce not only the impacts of deer farming on waterways, but also reduce greenhouse gas emissions.

\section{Economic considerations}

The success of sustainable management practices for deer farming not only depends on a sound understanding of the biophysical resources and interactions to validate effects of altered management intended to reduce environmental impacts, but also on the implementation and adoption of these practices by deer farmers. Although the deer farming community has already been proactive in taking initiatives to adopt sustainable farming practices, the balance between the costs versus the benefits of new techniques or practices will be an important driver for their successful adoption. It is therefore important that the economic implications of such techniques or management practices are investigated. This should include the direct costs (e.g. loss of productive land due to retirement of riparian areas) and benefits (e.g. ease of management, increased market access, maintaining New Zealand's green/clean image) to the deer farmer, as well as the total economic and resource costs (e.g. energy use, transport costs) of these techniques or practices. Environmental Resource Accounting provides a mechanism for estimating these economic and resource costs, as it not only accounts for the direct costs of a process, but also considers resource costs and environmental impacts (Ledgard et al. 2002). This could be of particular importance for the deer industry with the emerging concept of 'food miles'. Resource Accounting could be used to demonstrate the total resource costs of New Zealand deer products, which provides consumers with a direct comparison of these costs with those from competing markets.

\section{Conclusions}

The effects of deer farming on the environment (in particular soil and water quality) are well recognised, and are largely the results of the behavioural response of deer to stress and confinement. Anecdotal evidence suggests management practices to reduce environmental impacts including, the use of electric fences to protect tracks and wallows, provision of shade shelter to reduce stress, reducing stocking rate and maximising productivity per animal, and riparian planting to reduce contamination of waterways. However, very little experimental evidence exists on the extent of these impacts and further identification of sustainable management practices for deer farming requires more research to determine sediment, nutrient and faecal contaminant movement to waterways, and to calibrate currently available catchment modelling techniques. Research is also required on the impact of soil compaction, aquatic transmission of mammalian diseases and greenhouse gas emissions from deer farming. The success of potential sustainable management practices for deer farming also depends on the implementation and adoption of these practices, which will be influenced by the costs versus the benefits to New Zealand deer farmers and other stakeholders. It is therefore important that economic implications, both directly to the farmer as well as the resource and environmental costs, of such techniques or management practices are investigated.

\section{ACKNOWLEDGEMENTS}

The authors thank Bala Tikkisetty, Environment Southland; Ian Brown, Otago Regional Council; Murray Harris, Land and Forest Consultant; Keith Betteridge, Stewart Ledgard, Mike O'Connor and Jo Pollard, AgResearch; and Rob Davies-Colley and Bob Wilcock, NIWA, for valuable comments. This review was funded by DEEResearch Ltd.

\section{REFERENCES}

Anon 2000. Summary results of preliminary survey of BOP Deer Business Group.

Baisden, W.T.; Beets, P.; Carran, R.A.; Clark, H.; FortRobertsen, J.B.; Francis, G.S.; Mac laren, P.; Marshall, H.; Manning, M.R.; Newton, P.C.D.; Saggar, S.; Tate, K.R. 2001. An assessment of the significance to New Zealand of article 3.4. activities under the Kyoto Protocol. A report prepared for the Ministry of Agriculture and Forestry, Wellington, New Zealand.

Ball,A.; Till, D. 1998. Review of potential waterborne human pathogens in New Zealand. Report for the Ministry for Environment. ESR, Client Report CSC 97/22.

Boubée, J.; Dean, T.; West,D.W.; Barrier, R.F.G. 1997. Avoidance of suspended sediment by the mig ratory stage of six New Zealand native fish species. New Zealand Joumal of Marine and Freshwater Research 31: 61-69.

Clark, H. 2001. Ruminant methane emissions: a review of the methodology used for national inventory estimations. A report prepared for the Ministry of Agriculture and Fisheries by AgResearch.

Collins, R.P.; Rutherford, K. 2002. Modelling bacterial water quality from streams draining pastoral land. Water Research (Submitted).

Davies-Colley, R.J.; Hickey, C.W.; Quinn, J.M.; Ryan, P.A. 1992. Effects of clay discharges on streams: 1. Optical properties and epilithon. Hydrobiologia 248: 215-234. 
Davies-Colley, R.J.; Nagels, J.W. 2002. Effects of dairying on water quality of lowland streams in Westland and Waikato. Proceedings of the New Zealand Grassland Association 64: 107-114.

Davies-Colley, R.J.; Nagels, J.W.; Smith, R.; Young, R.; Phillips, C. 2002. Water quality impacts of cows crossing an agricultural stream, the Sherry River, New Zealand. In: The 6th IWA International Specialist Conference on Diffuse Pollution, Amsterdam, 30Sept-4 Oct 2002. (In press).

de Klein, C.A.M.; Clark, H. 2002. Potential mitigation options for reducing methane and nitrous oxide emissions from dairy farms. In: Dairy farm soil management. Occasional report Fertiliser and Lime Research Centre, Massey University, Palmerston North. pp. 233-246. Eds. Currie, L.D.; Lo gana than, P. de Klein, C.A.M.; Sherlock, R.R.; Cameron, K.C.; van der Weerden, T.J. 2001. Nitrous oxide emissions from agricultural soils in New Zealand - a review of current knowledge and directions for future research. Journal of The Royal Society of New Zealand 31: 543-574.

de Klein, C.A.M.; Sherlock, R.R.; Ledg ard, S.F.; Barton, L.; Kelliher, F.M.; Walcroft, A.S.; Rys, G. 2002. Nitrous oxide emissions from New Zealand agriculture: research to refine the national inventory. In: Non- $\mathrm{CO}_{2}$ Greenhouse Gases: Scientific understanding, control options and policy aspects. Proceedings of the Third International Symposium, Maastricht, The Netherlands. pp. 275-280. Eds. van Ham, J.; Baede, A. P. M.; Guicherit, R.; WilliamsJacobse, J. G. F. M., Millpress, Rotterdam, The Netherlands.

Elliot,A.H.; Carlson, W.T. 2002. Effects of sheep grazing on contaminant loss in surface runoff. Australian Journal of Soil Research (Submitted).

Elliott, A.H.; Tian, Y.Q.; Rutherford, J.C.; Carlson, W.T. 2002. Effect of cattle treading on interrill erosion from hill pasture: modelling concepts and analysis of rainfall simulator data. Australian Journal of Soil Research 40: (In press).

Envir onment Southland 2000. State of the environment report-Water. Environment Southland.

Eyles, R.; Niyogi, D.; Weinstein, P.; Townsend, T.; Brooks, H.; Trott, A. 2002. Ecosystem change and Campylobacter in freshwaters: a New Zealand perspective. Presented at the Society for Applied Microbiology Summer Conference:Pathogens in the environment and changing ecosystems. University of Nottingham, UK. 8-11 July 2002.

Freudenberger, D.O.; Burns, C.J.; Toyokawa, K.; Barry, T.N. 1994. Digestion and rumen metabolism of red clover and perennial ryegrass/white clover forages by red deer. Joumal of Agricultural Science 122: 115120.
Gill, J. 1998. Deer diseases - Otago and Southland. Proceedings, Deer Branch of the New Zealand VeterinaryAssociation 15: 171-174.

Hagedorn, C.; Robinson, S., L.; Filtz, J.R.; Grubbs, S.M.; Angier, T.A.; Reneau, R.B.J. 1999. Determining sources of fecal pollution in a rural Virginia watershed with antibiotic resistance patterns in fecal streptococci. Applied and Environmental Microbiology 65: 5522-5531.

Hoskin, S.O.; Wilson, P.R.; Barry, T.N.; Charleston, W.A.G.; Waghorn, G.C. 2000. Effect of forage legumes containing condensed tannins on lungworm (Dictyocaulus sp.) and gastrointestinal parasitism in young red deer (Cervus elaphus). Research in Veterinary Science 68: 223-230.

Jowett, I.G.; Boustead, N.C. 2001. Effects of substrate and sedimentation on the abundance of upland bullies (Gobiomorphus breviceps). New Zealand Journal of Marine and Freshwater Research 35: 605-613.

Ledgard, S.F.; Patterson, M.D.; Wedderburn, E.A.; Finlayson, J.F.; Carran, A. 2002. How eco-efficient is the Waika to dairy industry? Proceedings of the New Zealand Institute of Primary Industry Management and Rural Valuers Conference: 95-102.

Ledg ard, S.F.; Penno, J.W.; Sprosen, M.S. 1999a. Nitrogen inputs and losses from grass/clover pastures grazed by dairy cows, as affected by nitrogen fertilizer application. Journal of Agricultural Science 132: 215225.

Ledgard, S.F.; Williams, P.H.; Broom, F.D.; Thorrold, B.S.; Wheeler, D.M.; Willis, V.J. 1999b. OVERSEER $^{\mathrm{TM}}$ - A nutrient budgeting model for pastoral farming, wheat, potatoes, apples and kiwifruit. pp. 143-152.In: Best soil management practices for production. Eds. Currie, L. D.; Hedley, M. J.; Horne, D. J.; Loganathan, P. Fertilizer and Lime Research Centre, Masse y University, Palmerston North.

Malcolm, J. 1996. Conserving soil. The Deer Farmer June 1996: 47-51.

Masuko, T.; Souma, K.; Kumagai, H.; Takasaki, K.; Kameyama, Y.; Ishijima, Y. 1997. Digestibility and nitrogen balance in Yeso sika deer (Cervus nippon yesoensis) fed round baled hay, alfalfa hay cube and round baled silage. Grassland Science 43: 32-36.

McDowell, R.W.; Sharpley, A.N.; Beegle, D.B.; Weld, J.L. 2001a. Comparing phosphorus management strategies at a watershed scale. Journal of Soil and Water Conservation: 306-315.

McDowell, R.W.; Sharpley, A.N.; Condron, L.M.; Haygarth, P.M.; Brookes, P.C. 2001b. Processes controlling soil phosphorus release to runoff and implications for agricultural management. Nutrient Cycling in Agroecosystems: 269-284.

McTagg art, I.P.; Douglas, J.T.; Clayton, H.; Smith, K.A. 
1997. Nitrous oxide emission from slurry and mineral nitrogen fertilizer applied to grassland. pp. 201-209. In: Gaseous nitrogen emissions from grasslands. Eds. Jarvis, S. C.; Pain, B. F. CAB International, Wallingford, UK.

Ministry for the Environment 2001. Deer farming and riparian management in Southland. pp. 130-134. In: Managing waterways on farms. A guide to sustainable water and riparian management in rural New Zealand. Eds. Ministry for the Environment, Wellington, New Zealand.

Ministry of Agriculture and Forestry 2001a. Animal population statistics. http://www.maf.govt.nz/ statistics/primaryindustries

Ministry of Agriculture and Forestry 2001b. Deer monitoring report. North Island Deer. http:// www.maf.g ovt.nz/mafnet/rural-nz/statistics-andforecasts/farm-monitoring/deer-2001/httoc.htm

Ministry of Agriculture and Forestry 2001c. Farm monitoring reports. http://www.maf.govt.nz/mafnet/ rural-nz/statistics-and-forecasts/farm-monitoring/ index.htm

Monaghan, R.M.; Paton, R.J.; Smith, L.C.; Binet, C. 2000. Nutrient losses in drainage and surface runoff from a cattle-grazed pasture in Southland. Proceedings of the New Zealand Grassland Association 62: 99104.

Moore, G.H.; Cowie, G.M.; Bray, A.R. 1985. Herd management of farmed red deer. Biology of Deer Production, Royal Society Bulletin 22: 343-355.

New Zealand Climate Change Programme 2001. Kyoto Protocol - Ensuring our Future. Climate Change Consultation Paper. Ministry for the Environment, Wellington. 44p.

Ne w Zealand Deer Farmers' Association 2001. The 2002 Deer Farmers' Environmental Awards. New Zealand Deer Farmers' Association, Wellington, New Zealand.

New Zealand Game Industry Board 2001. Submission on the Climate Change Consultation paper 'Kyoto Protocol-ensuring our future'. New Zealand Game Industry Board, Wellington, New Zealand.

Nguyen, L.; Nagels, J.; Sukias, J. 2002a. Faecal Contamination and the removal of Escherichia Coli (E. Coli) in drainage ditches. In: Dairy farm soil management. Occasional report Fertiliser and Lime Research Centre, Massey University, Palmerston North. pp. 261-266. Eds. Currie, L.D.; Loganathan, P. Nguy en, L.; Sukias, J.; Nagels, J.; Reeves, P. 2002b. Ecological function of drainage ditches in attenuating ammonium and phosphorus pollutants from dairy farms. In: Dairy farm soil management. Occasional report Fertiliser and Lime Research Centre, Massey University, Palmerston North. pp. 255-260. Eds. Currie, L.D.; Loganathan, P.
Nguyen, M.L.; Sheath, G.W.; Smith, C.M.; Cooper, A.B. 1998. Impact of cattle treading on hill land 2. Soil physical properties and contaminant runoff. New Zealand Journal of Agricultural Research 41: 279290.

Otago Regional Council 1996. Riparian Management.

Parkyn, S.; Matheson, F.; Cooke, J.; Quinn, J.M. 2002. Review of the environmental effects of a griculture on freshwaters NIWA client report FGC02206.

Pollard, J.C. 2001. Providing shade and shelter. New Zealand Deer Farming Annual 36-38.

Pollard, J.C.; Drewry, J.J. 2002. Calving environments for farmed red deer: a review of current knowledge and a pilot study on soil quality. Proceedings, Deer Branch of the New Zealand Veterinary Association 19: 97-104.

Quinn, J.M.; Davies-Colley, R.J.; Hic key, C.W.; Vickers, M.L.; Ryan, P.A. 1992. Effects of clay discharges on streams, 2. Benthic invertebrates. Hydrobiologia 248: 235-247.

Rodda, H.J.E.; Stroud, M.J.; Shankar, U.; Thorrold, B.S. 2001. A GIS based approach to modelling the effects of land-use change on soil erosion in New Zealand. Soil Use and Management 17: 30-40.

Rowarth, J.S.; Goldson, S.L.; Pearse, A.J.T. 2000. Future needs: current tools. Address to the research Forum, $25^{\text {th }}$ NZDFA Conference. Proceedings, Deer Branch of the New Zealand Veterinary Associa tion 17: 5-8.

Rowe, D.; Hicks, M.; Richardson, J. 2000. Reduced abundance of banded kokopu (Galaxias fasciatus) and other native fish in turbid rivers of the North island of New Zealand. New Zealand Journal of Marine \& Freshwater Research 34: 547-558.

Savill, M.G.; Murray, S.R.; Scholes, P.; Maas, E.W.; McCormick, R.E.; Mooer, E.B.; Gilpin, B.J. 2001. Application of polymerase chain reaction (PCR) and TaqMan PCR techniques to the detection and identification of Rhodococcus coprophilus in faecal samples. Journal of Microbiological Methods 47: 355368.

Sheath, G.W.; Carlson, W.T. 1998. Impact of cattle treading on hill land. 1. Soil damage patterns and pasture status. New Zealand Journal of Agricultural Research 41: 271-278.

Suren, A.M.; Jowett, I.G. 2001. Effects of deposited sediment on invertebrate drift: an experimental study. New Zealand Journal of Marine and Freshwater Research 35: 725-737.

Thorrold, B.; Trolove, M. 1996. Erosion on deer farms in the Ngongotaha Valley. A report on field measurements and observations.

van Vuuren, A.M.; Meijs, J.A.C. 1987. Effects of herbage composition and supplement feeding on the excretion of nitrogen in dung and urine by grazing 
dairy cows. pp. 17-25. In: Animal Manure on Grassland and Fodder Crops. Eds. van der Meer, H.G.; Unwin, R. J.; van Dijk, T.A.; Ennik, G.C. Martinus Nijhof Publishers, Dordrecht, The Netherlands.

Waghor n, G.C.; Sheldon, I.D. 1997. Effect of condensed tannins in Lotus corniculatus on the nutritive value of pasture for sheep. Journal of Agricultural Science 128: 365-372.

Waters, T.F. 1995. Sediment in streams: sources, biological effects and control. Bethseda, Maryland, American Fisheries Society.

Williams, P.H.; Haynes, R.J. 1995. Effect of sheep, deer and cattle dung on herbage production and soil nutrient content. Grass \& Forage Science 50: 263-271.

Woodward, S.L.; Waghorn, G.C.; Ulyatt, M.J.; Lassey, K.R. 2001. Early indications that feeding Lotus will reduce methane emissions from ruminants. Proceedings of the New Zealand Society of Animal Production 61: 23-26. 